\title{
LATE HOLOCENE CLIMATIC CHANGE IN THE BALKANS: SPELEOTHEM ISOTOPIC DATA FROM SERBIA
}

\author{
Aleksander Kacanski ${ }^{1} \bullet$ Israel Carmi $^{2} \bullet$ Aldo Shemesh $^{2} \bullet$ Joel Kronfeld $^{1,3} \bullet$ Ruth Yam $^{2} \bullet$ \\ Akiva Flexer ${ }^{1}$
}

ABSTRACT. A detailed profile of the stable isotopes of carbon and oxygen was obtained from a speleothem (stalagmite) from the Ceremosjna Cave in eastern Serbia. The stalagmite is a low magnesian calcite that did not show any evidence of diagenetic alteration. It was precipitated under isotopic equilibrium conditions from dripping water. The age and rate of deposition was derived from six internally consistent radiocarbon dates. The initial ${ }^{14} \mathrm{C}$ activity was determined to be approximately $80 \mathrm{pMC}$. The stalagmite appears to preserve a continuous record of calcite deposition from approximately $2300 \mathrm{BP}$ until the present.

Oxygen isotopic data, based upon 100 samples, are used to derive the first paleotemperature record for Serbia. A regression analysis of the all the data indicates that over the period of time that the speleothem was deposited there was a general trend of lowering of the average temperature. Superimposed upon this are significant long-term temperature fluctuations. These can be divided into four broader climatic groupings. Going from the oldest times to the present, there are two warm periods separated by a period when the temperatures fell below the temperature trend line. However, the absolute temperatures were generally above those of the more recent period that is generally characterized by the coolest climatic conditions.

\section{INTRODUCTION}

Much work is being done at present to use the stable isotopic composition of speleothems to reconstruct continuous paleoclimatic profiles, extending back over periods of thousands of years, for many parts of the world. Where equilibrium conditions prevail, the analysis of the oxygen isotopic composition of carbonate speleothems can be used as indicators of paleotemperature (providing no subsequent re-crystallization has occurred). Hendy and Wilson (1968) have demonstrated that the oxygen isotopic composition of speleothem calcite is a function of the isotopic composition of the seepage water and the temperature at which the calcite precipitates. In isolated cave compartments, the average air temperature is equal to the mean annual surface temperature. Where the humidity is $100 \%$ there is no evaporation of the seepage water, and this may obviate the introduction of kinetic fractionation effects. The oxygen isotopic composition in the cave seepage water is derived from the average oxygen isotopic composition of the rain that percolates through the soil and is altered by the equilibrium reaction with the host rock $\mathrm{CO}_{2}$. This isotopic exchange, at equilibrium, is temperature dependent. It is well known that the oxygen isotopic composition of rainwater is dependent upon local temperature and the ${ }^{18} \mathrm{O}$ content of water vapor in the rain bearing clouds (Dansgaard, 1964). The oxygen isotopic composition in the cave water is derived from the average composition of the rain that percolates through the soil and is altered by the (temperature dependent) isotopic exchange at equilibrium with the carbonate of the surrounding rock.

The stable isotopic composition of carbon in speleothems has been used as well to deduce paleoclimatic or paleoecological changes. The carbon in the speleothems is derived from dissolution of the carbonate bedrock and from carbon dioxide released from respiration and decay of plants in the soil zone overlying the cave. Plants with $\mathrm{C}_{3}$ and $\mathrm{C}_{4}$ primary photosynthesis reactions yield isotopically distinct signatures in their soil gases, $\mathrm{C}_{4}$ plants being typical to more arid environments. The isotopic signature of the flora of the overlying terrain is archived in the speleothem carbonate minerals, which may serve as a proxy for climatic data. The present study was carried out in an attempt to use

${ }^{1}$ Department of Geophysics and Planetary Sciences, Tel Aviv University, Ramat Aviv, Israel

${ }^{2}$ Department of Environmental Sciences and Energy Research, The Weizmann Institute of Science, Rehovot, Israel

${ }^{3}$ Corresponding author. Email: yoelk@post.tau.ac.il.

(C) 2001 by the Arizona Board of Regents on behalf of the University of Arizona Radiocarbon, Vol 43, Nr 2B, 2001, p 647-658

Proceedings of the 17 th International ${ }^{14} \mathrm{C}$ Conference, edited by I Carmi and $\mathrm{E}$ Boaretto 
the stable isotopic composition of a calcite speleothem, to provide a partial late Holocene record of the climate change in the Balkans, where such information is lacking.

The speleothem analyzed in this study was a stalagmite taken from the floor of the Ceremosnja Cave. The cave is located in the Homolje mountains, of eastern Serbia, which are parts of the larger Carpato-Balcanian mountain range (Figure 1). The cave is situated at an elevation of $\sim 530 \mathrm{~m}$. The entrance is no more than $20 \mathrm{~m}$ from the hill top, at the base of a 12-m-high cliff, at the end of a blind valley formed by the Strugar Spring. The cave is situated within a small hill, whose catchment is less than $1 \mathrm{~km}^{2}$.

The cave is formed within thick-bedded, massive marine carbonates of lower Cretaceous age. The thickness of the host rock limestones and dolomites varies from 80 to $200 \mathrm{~m}$. The cave itself is formed at the approximate contact between the karstic carbonates and a crystalline schist of Proterozoic age. Within the schist are apparently andesite and dacite intrusions. The cave is divided into five halls, with the Strugar Stream running through it (Figure 2). The Strugar Stream connects the Ceremosnja Cave with the nearby Bigar Cave, which is one of two other large caves situated in the region. There is an abundance of water in the Ceremosjna Cave. The stream channel splits into two branches within the cave, though the surface connection between the two is disrupted for several tens of meters as one branch flows underground. The perennially flowing water has kept the relative humidity of the cave high. Measurements of the relative humidity of the cave were carried out in 1976 (Lazarevic 1988). The relative humidity from the andesite hall where the stalagmite was collected was $100 \%$.

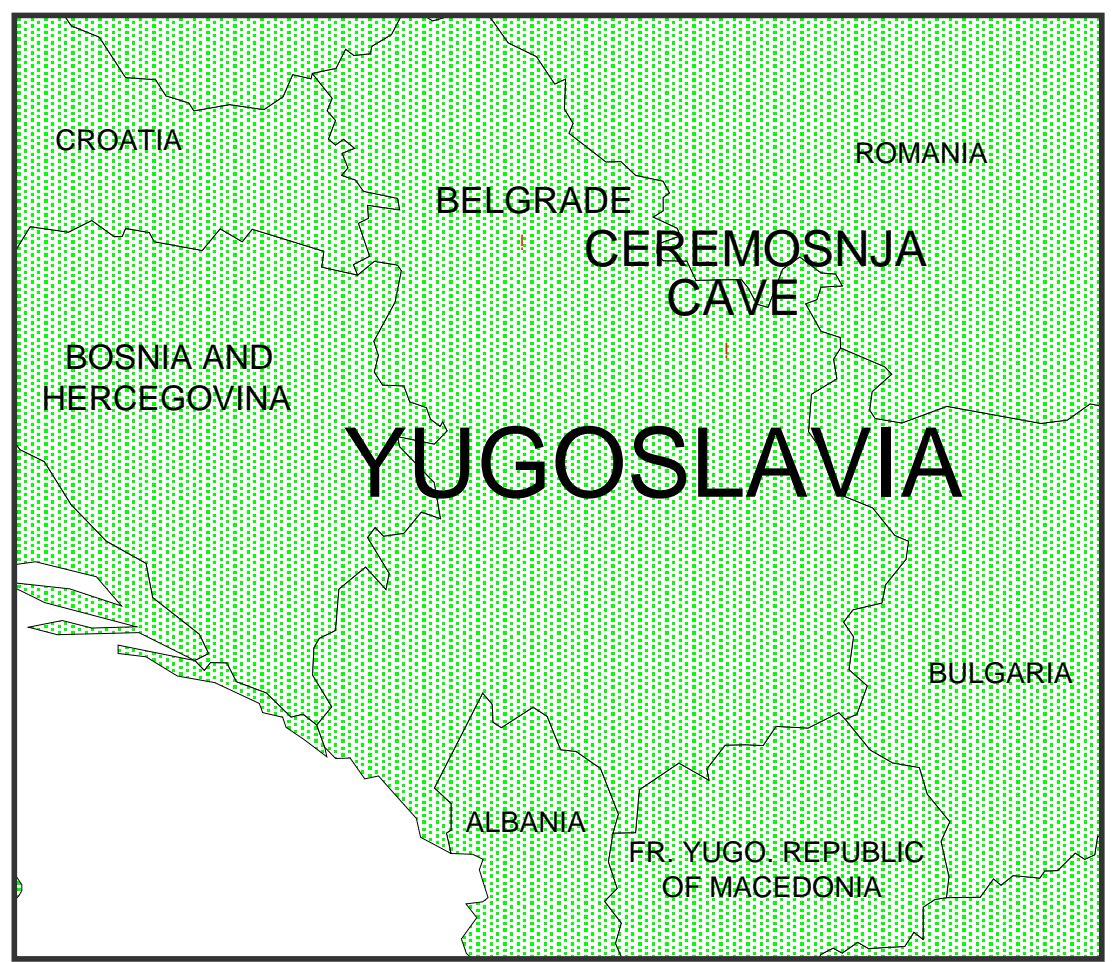

Figure 1 Sample locator map, showing the position of the Ceremosnja Cave in eastern Serbia 


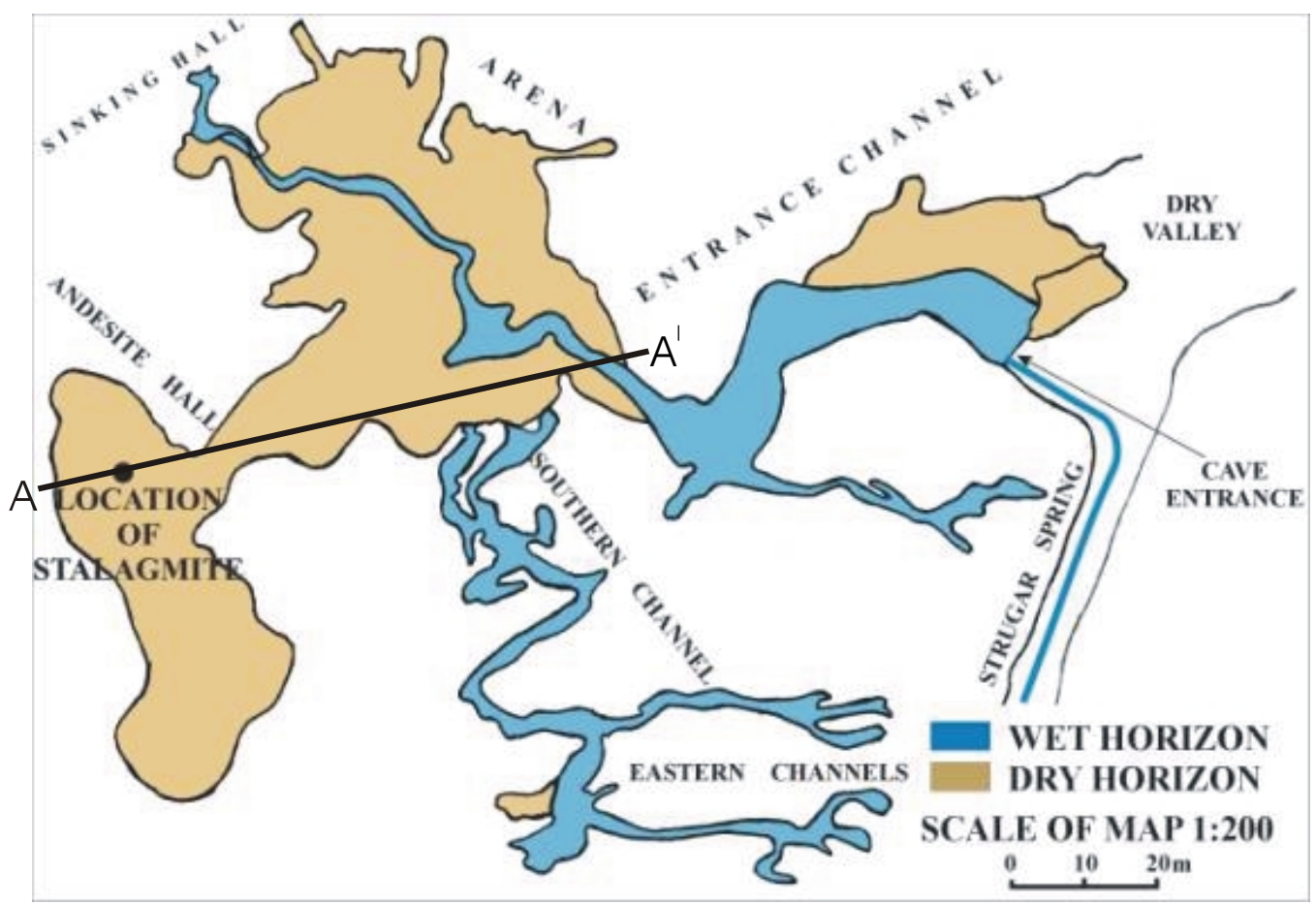

Figure 2 A speleological map of the Ceremosnja Cave. The dry and wet areas are delineated.

The site from which the studied stalagmite was taken is shown in Figure 2 and the cave profile is presented in Figure 3. The speleothem was taken in a part of the cave, called the andesite hall, in which andesite makes up part of the cave walls and ceiling.

\section{METHODS}

A single, densely crystalline, flat topped stalagmite was collected from the floor of the andesite chamber of Ceremosnja Cave. The stalagmite was found lying horizontally on the floor of the cave. Apparently, it had fallen over, being too heavy for the clay substrate, on which it was growing, to support.

This speleothem was $33 \mathrm{~cm}$ in length and varied between 10 and $18 \mathrm{~cm}$ in circumference. It was elliptical in shape, with a beige colored outer surface. When cut, it exhibited growth rings that were generally pure white in color. This gave way periodically to thin growth bands that were of various shades of beige. The stalagmite was cut at first along its base, to determine if the speleothem was suitable for study. This included insuring that there was no recrystallization, and that the stalagmite was a single unit, growing outward from a single core. After the base had been cut and polished, the remainder of the speleothem was cut into four parallel slices perpendicular to the growth axis. The three lower slices were each $4 \mathrm{~cm}$ thick. The top section of the stalagmite was left $\sim 20 \mathrm{~cm}$ thick. Samples were taken for mineralogical, chemical, and porosity study using a JEOL -840 Scanning Electron Microscope (SEM), with a Link $10000 \mathrm{X}$-ray spectrometer (EDS) attachment. Five samples were taken for both carbon and oxygen isotope analysis from a single growth layer along an axial traverse from the top section. This was done to evaluate the state of isotopic equilibrium during deposition (Hendy 1971). From one half of the polished basal section 100 consecutive samples were collected from the inner core to the speleothem surface. Six samples, each of about $25 \mathrm{~g}$, were cut for ${ }^{14} \mathrm{C}$ analyses. 


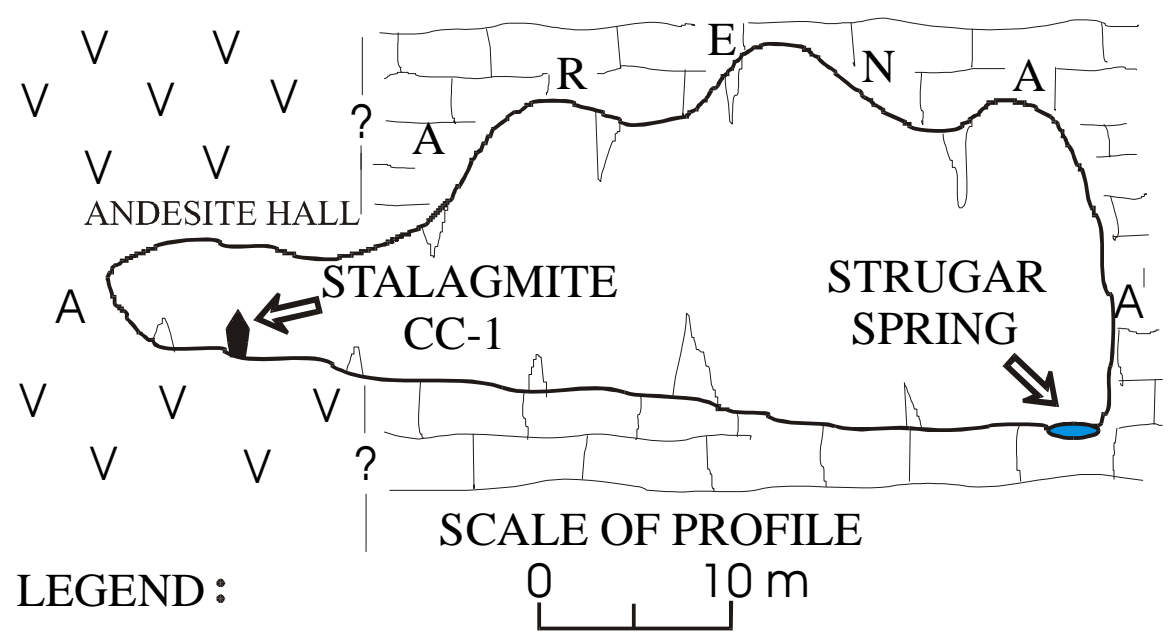

\section{CALCITE}

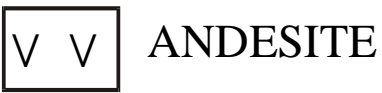

\section{-? - CONTACT OBSCURED}

Figure 3 A cross section of the Ceremosnja Cave showing the location of the stalagmite that was collected in the andesite hall.

The powdered samples taken by the drill to be used for oxygen and carbon isotopic analyses were dissolved in $100 \%$ dry $\mathrm{H}_{3} \mathrm{PO}_{4}$ to evolve $\mathrm{CO}_{2}$. The carbon dioxide gas was then introduced into a Finnigan MAT 250 mass spectrometer. The results of the carbon and oxygen isotopic analyses are reported in $\delta$ units, as per mil (\%o) deviations from the Vienna Peedee beleminite (VPDB) standard. The Vienna Standard Mean Ocean Water (VSMOW) was used for ${ }^{18} \mathrm{O}$, in the water samples. The relationship between the two standards is given by $\delta^{18} \mathrm{O}_{\mathrm{VPDB}}=\left(\delta^{18} \mathrm{O}_{\mathrm{VSMOW}}-30.91\right) / 1.0391$. All samples were run in duplicate. Where there was a discrepancy between the runs, or if the analyses exhibited fluctuations significantly different from the trend of the surrounding sample measurements, the samples were remeasured at least once. The analytical precision is $0.1 \%$ for both the oxygen and carbon measurements.

${ }^{14} \mathrm{C}$ analyses and tritium analyses were performed by liquid scintillation counting at the ${ }^{14} \mathrm{C}$ laboratory of the Weizmann Institute of Science. The acid solution that remained after the $\mathrm{CO}_{2}$ was generated in the radiocarbon procedure was saved for the innermost and outermost samples. The solutions were then used in an attempt to get a corroborating absolute age by the ${ }^{230} \mathrm{Th} /{ }^{234} \mathrm{U}$ method. The uranium and thorium isotopic analyses were carried out using standard procedures. This involved isotope dilution (using a ${ }^{232} \mathrm{U}-{ }^{228}$ Th spike), ion exchange and solvent extraction (Ivanovich and Harmon, 1992). The purified metals were electroplated on a stainless steel disc and analyzed by alphaspectrometry using a silicon surface barrier detector and an Ortec 575A alpha-spectrometer coupled to an Ortec-Norland 5510 Multichannel Analyzer. 
Samples of water from the Strugar Stream in the cave, before it entered the cave, and after it exited the cave were collected. Water samples for isotopic analyses were taken from a pond in the cave that was actively collecting seepage water. Several samples of rainwater and snow from the city of Belgrade were also collected. The oxygen isotopic composition was analyzed using the Finnegan MAT 250 mass spectrometer.

\section{RESULTS}

The SEM analyses confirmed that the speleothem was composed of a dense, pure calcite having compact crystals of low magnesium calcite. The average Ca concentration was $37.1 \%$ while the $\mathrm{Mg}$ concentration averaged only $0.02 \%$. There did not appear to be other metals present above the limit of detection of the instrument. It was thus not possible to differentiate between different growth layers upon the basis of chemical differences. The speleothem appeared to be impermeable with no secondary porosity or recrystallization.

The results of the carbon isotopic analyses are presented graphically in Figure 4 as a function of their position on the stalagmite. The carbon isotopes range from $\delta^{13} C_{\mathrm{VPDB}}=-8$ to $-3 \%$. The oxygen isotopic analyses are presented graphically in Figure 5. The oxygen isotopic measurements range from $\delta^{18} \mathrm{O}_{\mathrm{VPDB}}=-6.3$ to $-7.9 \%$.

The $\delta^{18} \mathrm{O}$ in the calcite precipitating in isotopic equilibrium with the dripwater did not increase along the specific growth layer that was sampled downwards from the apex of the stalagmite. It was concluded that there was no indication of sympathetic variation between the carbon and oxygen isotopic measurements. This strengthened our conviction that the speleothem was deposited in conditions of equilibrium (Hendy 1971) between the water and the calcite.

The ${ }^{14} \mathrm{C}$ analyses of the stalagmite are reported in Table 1 , along with the average $\delta^{13} \mathrm{C}$ for the representative interval. The ${ }^{14} \mathrm{C}$ activity decreased in a consistent fashion from the outer to inner samples, going from $80.5 \mathrm{pMC}$ (percent modern carbon) to $60.7 \mathrm{pMC}$. The standard deviation $( \pm)$ associated with the measurement, is derived from the counting statistics, and is reported at the one $\sigma$ level of confidence. The rate of growth of the stalagmite was approximately $0.15 \mathrm{~mm} / \mathrm{yr}$. Typical growth rates for speleothems growing in temperate regions often grow at a slower pace, in the range of $0.05-0.1 \mathrm{~mm} / \mathrm{yr}$ (Schwarcz, 1986). Thus the resolution in our speleothem is relatively high for paleoclimatic interpretation.

Table 1 The radiocarbon $\left({ }^{14} \mathrm{C}\right)$ age, using $80 \mathrm{pMC}$ for $\mathrm{A}_{0}$, and concentration of pMC and ${ }^{13} \mathrm{C}(\mathrm{PDB})$ from the samples (representative interval).

\begin{tabular}{ccccc}
\hline Sample & $\begin{array}{c}\text { Distance from center } \\
\text { range of sample }(\mathrm{cm})\end{array}$ & $\begin{array}{c}\delta^{13} \mathrm{C} \\
(\mathrm{PDB})\end{array}$ & $\mathrm{pMC}$ & $\begin{array}{c}{ }^{14} \mathrm{C} \text { age using } 80 \mathrm{pMC} \\
\text { for } \mathrm{A}_{0}(\mathrm{BP})\end{array}$ \\
\hline $\mathrm{K} 1$ & $14-13.2$ & -4.0 & $80.4 \pm 0.4$ & Modern \\
$\mathrm{K} 2$ & $13.2-10.7$ & -6.4 & $72.8 \pm 0.4$ & $740 \pm 45$ \\
$\mathrm{~K} 3$ & $10.7-5.9$ & -7.6 & $68.3 \pm 0.3$ & $1255 \pm 35$ \\
$\mathrm{~K} 4$ & $5.9-4.5$ & -7.6 & $65.8 \pm 0.3$ & $1555 \pm 35$ \\
$\mathrm{~K} 5$ & $4.5-2$ & -7.7 & $62.1 \pm 0.3$ & $2020 \pm 40$ \\
$\mathrm{~K} 6$ & $2-0$ & -7.7 & $60.7 \pm 0.3$ & $2200 \pm 40$ \\
\hline
\end{tabular}




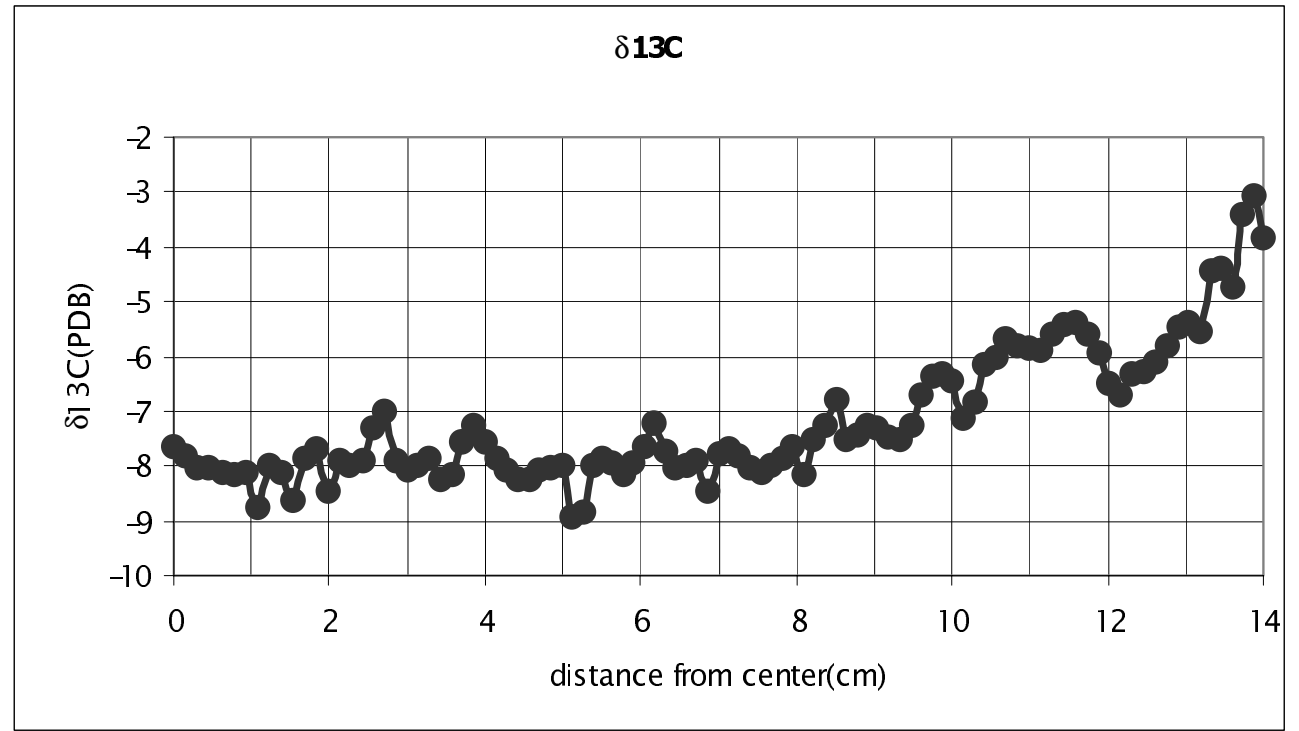

Figure 4 The change in the $\delta^{13} \mathrm{C}$ values as a function of distance, going from the center of the stalagmite outwards

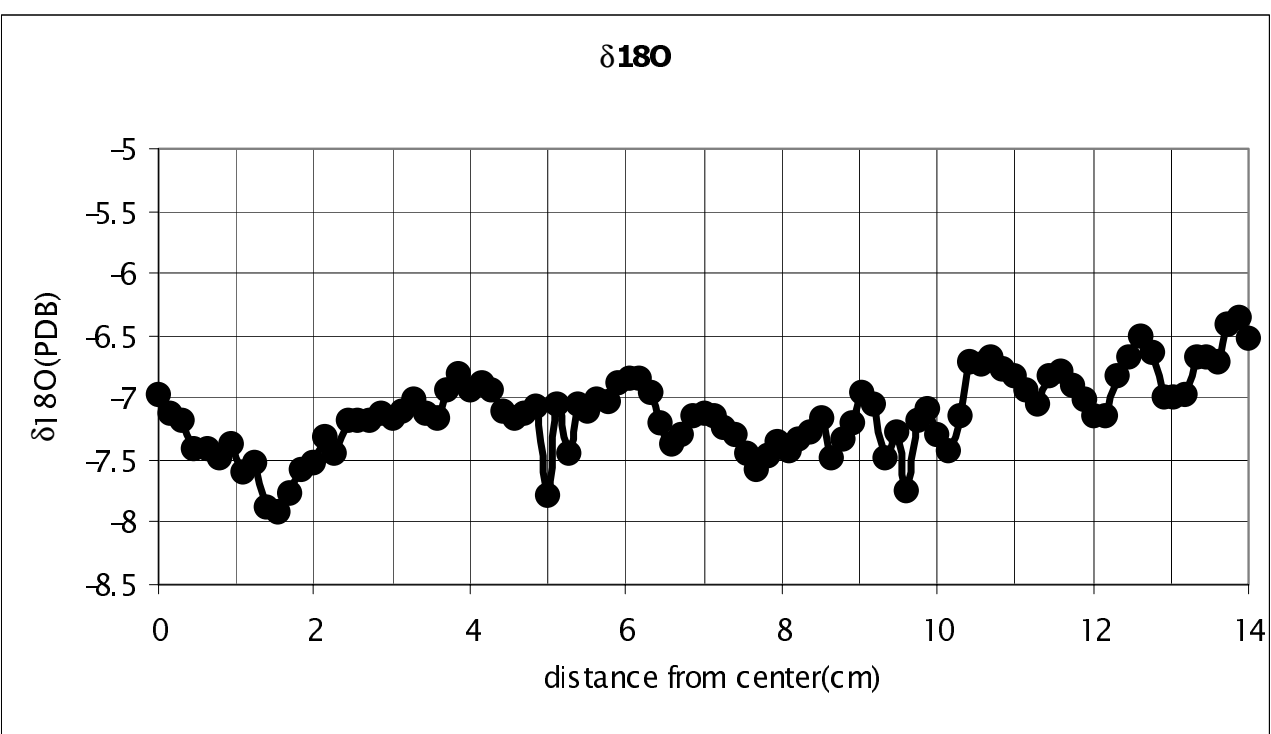

Figure 5 The change in the $\delta^{18} \mathrm{O}$ values as a function of distance, going from the center of the stalagmite outwards 
The oxygen isotopes of the rain and the water in the cave are reported in Table 3. The tritium value (in 1998) of the water from the small pond that collected the cave seepage was $13.6 \pm 0.3 \mathrm{TU}$. The ${ }^{14} \mathrm{C}$ activity of the same water 117 pMC.

The uranium-series isotopic analyses and the apparent ${ }^{230} \mathrm{Th} /{ }^{234} \mathrm{U}$ ages of the innermost and outermost speleothem samples are reported in Table 4. The uranium concentration was low, 0.07-0.08 ppm and the ${ }^{230} \mathrm{Th} /{ }^{232} \mathrm{Th}$ ratios were very low, $<2$.

Table 2 The carbon and oxygen isotopic data for the same flow layer to test the equilibrium conditions

\begin{tabular}{cccc}
\hline Sample & $\begin{array}{c}\delta^{13} \mathrm{C} \\
(\mathrm{PDB})\end{array}$ & $\begin{array}{c}\delta^{18} \mathrm{O} \\
(\mathrm{PDB})\end{array}$ & $\begin{array}{c}\text { Distance from } \\
\text { the top }(\mathrm{cm})\end{array}$ \\
\hline B1 & -6.57 & -7.21 & 0 \\
B2 & -6.31 & -7.29 & 2 \\
B3 & -5.72 & -7.06 & 4 \\
B4 & -5.87 & -7.11 & 6 \\
B5 & -6.03 & -7.18 & 8 \\
\hline
\end{tabular}

Table 3 The $\delta^{18} \mathrm{O}_{(\mathrm{SMOW})}$ values for precipitation in Belgrade and the Ceremosnja cave area

\begin{tabular}{lll}
\hline & & \multicolumn{1}{c}{$\begin{array}{c}\delta^{18} \mathrm{O} \\
(\mathrm{SMOW})\end{array}$} \\
\hline Sample & Sample location & -17.36 \\
SA-2 & Snow next to the cave & -11.03 \\
SA-3 & Dring water outside of cave, before entering the cave & -10.98 \\
SA-4 & Water accumulated in a small pond within the cave & -10.77 \\
SA-5 & Stream that drains the cave & -10.76 \\
SA-6 & Snow from Belgrade & -7.87 \\
SA-7 & Rain from Belgrade on March 7, 1999 & -10.16 \\
SA-8 & Rain from Belgrade on March 31, 1999 & -6.04 \\
SA-9 & Rain from Belgrade on April 2, 1999 & -3.87 \\
SA-10 & Rain from Belgrade on April 3, 1999 & -5.11 \\
SA-11 & Rain from Belgrade on April 11, 1999 & -9.05 \\
SA-12 & Rain from Belgrade on April 12, 1999 & -7.16 \\
SA-13 & Rain from Belgrade on April 17, 1999 & -8.19 \\
SA-14 & Rain from Belgrade on April 18, 1999 & -8.10 \\
SA-15 & Rain from Belgrade on April 20, 1999 & -10.52 \\
SA-16 & Rain from Belgrade on April 22, 1999 & -1.30 \\
SA-17 & Rain from Belgrade on April 24, 1999 & -4.02 \\
SA-18 & Rain from Belgrade on April 26, 1999 & -7.94 \\
SA-19 & Rain from Belgrade on May 1, 1999 & -3.77 \\
\hline
\end{tabular}

Table 4 Uranium and thorium isotopic data from the alpha-spectrometric analyses of the inner and outer layers of the stalagmite

\begin{tabular}{lcccc}
\hline Sample & $\mathrm{U}(\mathrm{ppm})$ & $\begin{array}{c}{ }^{234} \mathrm{U} / 238 \mathrm{U} \\
\text { (activity ratio) }\end{array}$ & $\begin{array}{c}{ }^{230} \mathrm{Th} /{ }^{232} \mathrm{Th} \\
\text { (activity ratio) }\end{array}$ & $\begin{array}{c}{ }^{230} \mathrm{Th} /{ }^{234} \mathrm{U} \\
\text { (activity ratio) }\end{array}$ \\
\hline $\mathrm{A} 1$ & $0.084 \pm 0.003$ & $1.15 \pm 0.04$ & $1.93 \pm 0.36$ & $0.049 \pm 0.006$ \\
$\mathrm{~A} 6$ & $0.070 \pm 0.003$ & $1.12 \pm 0.06$ & $1.89 \pm 0.39$ & $0.056 \pm 0.007$ \\
\hline
\end{tabular}




\section{DISCUSSION}

The isotopic analyses, both for oxygen and carbon, show large fluctuations over the time that the speleothem was deposited. As the calcite of the speleothem was deposited in equilibrium with the drip water, these changes should reflect climatic conditions outside of the cave for the intervals measured. The oxygen isotopic composition of the drip water is a function of ambient air temperature and the isotopic composition in the water vapor. The cave temperature, can be calculated from the equilibrium equation (Craig 1965), from:

$$
\mathrm{T}=16.9-4.2 \times\left(\delta^{18} \mathrm{O}_{\mathrm{c}^{-}} \delta^{18} \mathrm{O}_{\mathrm{w}}\right)+0.13 \times\left(\delta^{18} \mathrm{O}_{\mathrm{c}}-\delta^{18} \mathrm{O}_{\mathrm{w}}\right)^{2},
$$

where,

$\delta^{18} \mathrm{O}_{\mathrm{c}}=$ the oxygen isotopic composition of the carbonate rock (PDB standard)

$\delta^{18} \mathrm{O}_{\mathrm{w}}=$ the oxygen isotopic composition of the cave water (SMOW standard) from which the calcite precipitated.

Thus, the oxygen isotopic composition of the speleothem calcite can yield a record of the temperature changes from the core to the outer portions of the stalagmite (Figure 5). Significant temperature changes are indeed in evidence. In Figure 6, the temperature fluctuations are interpreted as falling into four general groupings. From the oldest to the youngest, a warm period is followed by an intermediate period again followed by a warm period, terminating in a colder period lasting up into the present. In the lattermost period, the average temperature is $\sim{ }^{\circ} \mathrm{C}$ lower than the average temperature in the "intermediate" period, though its highest temperatures were similar to the average of that period. The most extreme temperature during the warm periods was up to $5{ }^{\circ} \mathrm{C}$ higher than the present. This climatic generalization that is presented in the speleothem is not chronologically congruent with the timing of the climate changes that transpired in western Europe, such as the warm Roman period, Medieval Warm period, or the Little Ice Age (e.g. Goudie 1994)

To convert the relative oxygen isotopic changes to absolute temperature we must know the absolute oxygen isotopic composition of the modern precipitation of the study area. The mean temperature, which is an average from 1887 to 1995 , is $11.6{ }^{\circ} \mathrm{C}$. If the $\delta^{18} \mathrm{O}$ value for the pond that collects the drip water is taken, which is approximately $-10 \%$ (SMOW), too low values for the present average annual temperature are derived. (Perhaps the analysis of the pond drip water, which was taken in March 1999, includes too great an influence of the snow melt, which should be considerably depleted in ${ }^{18} \mathrm{O}$ compared to the rain). On the other hand, if an average of the oxygen isotopic values for rain (Table 3) from Belgrade (in the spring) is taken, a value of $-6.6 \%$ (SMOW) is obtained. Too high a value (approximately $15{ }^{\circ} \mathrm{C}$ ) for the present average annual temperature would be obtained, if this value is used in conjunction with the measured calcite value for the most recent section of the speleothem. For the most recent section of the speleothem to yield a good approximation of today's average annual temperature in the area of the Ceremosnja Cave, the calcite would have had to have precipitated from water having an oxygen isotopic value of $-8 \%$ (SMOW). As temperatures can be reconstructed from the stalagmite calcite, it is therefore, it is very important to define when these changes occurred. The clear trend of decreasing ${ }^{14} \mathrm{C}$ inwards, indicates that the ${ }^{14} \mathrm{C}$ signature was preserved and not altered after deposition. The ages can be calculated from the change in the ${ }^{14} \mathrm{C}$ by the formula:

$$
\text { Age }=8030 \ln \mathrm{A}_{0} / \mathrm{A},
$$

where: $\mathrm{A}_{0}$ is the initial ${ }^{14} \mathrm{C}$ activity, and $\mathrm{A}$ the measured ${ }^{14} \mathrm{C}$ activity. 


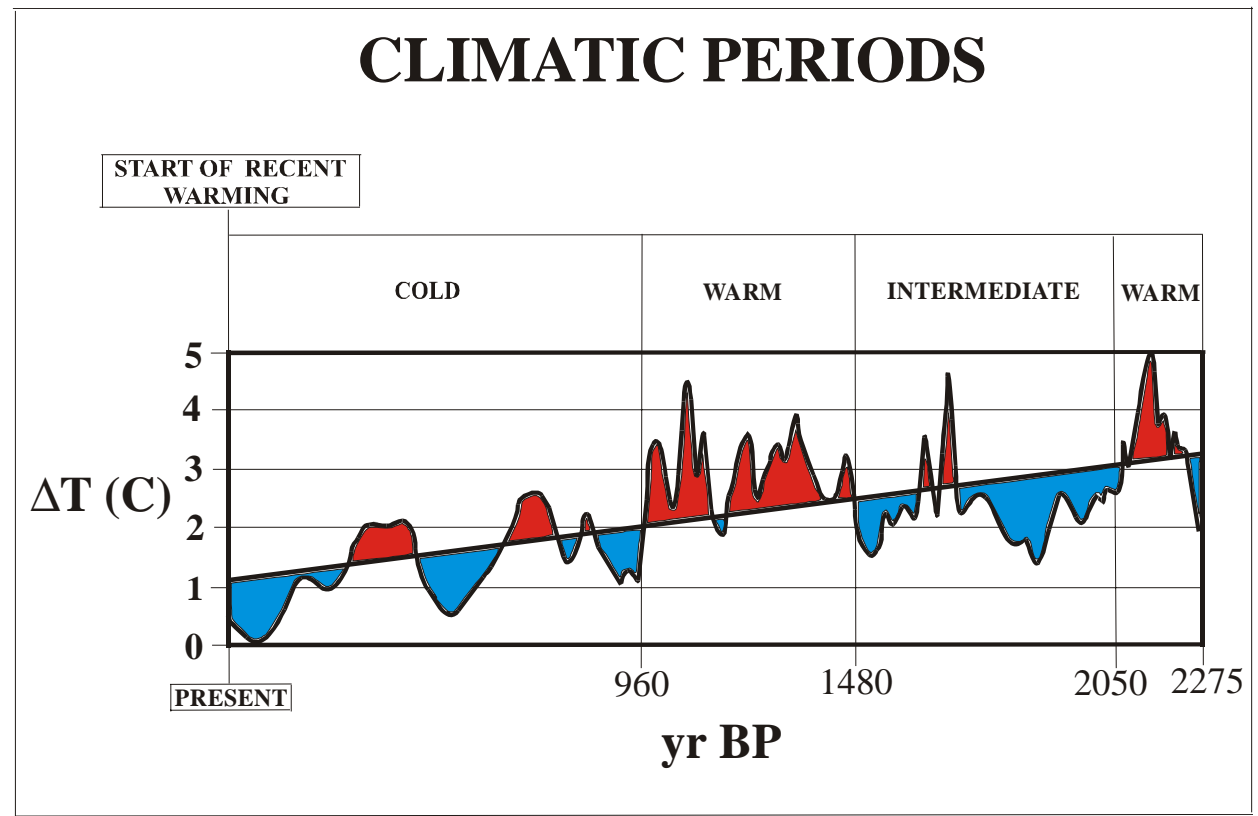

Figure 6 The average temperature appears to be declining over the past $2300 \mathrm{yr}$. Superimposed upon this trend are significant temperature deviations that may be classified into four climatic groupings.

Plants take up a uniform activity of ${ }^{14} \mathrm{C}$, defined to be $100 \mathrm{pMC}$ (before the introduction of excess ${ }^{14} \mathrm{C}$ due to atmospheric nuclear testing). This value can not be used in dating of groundwater. In fact, the initial ${ }^{14} \mathrm{C}$ activity in groundwater at any location is not a priori a known parameter. For the Ceremosnja Cave area, $\mathrm{A}_{0}$ was determined with the aid of the tritium concentration in conjunction with the concomitantly measured ${ }^{14} \mathrm{C}$ activity of the seepage water. The tritium concentration (Table 5) for the seepage puddle, as noted above, was 13.6 $\pm 0.3 \mathrm{TU}$ in 1998. This value was compared with the tritium concentration in rain for which the International Atomic Energy Agency has a record (http:/isohis.iaea.org). The closest site of continuous monitoring is for the city of Zagreb. By comparing the yearly tritium in precipitation in Zagreb with the decay-corrected tritium in the seepage (Table 5), the closest correlation between the tritium concentrations of the two areas appears to have occurred in 1989. Therefore, rain that dripped through the cave fell on the top of the cave in the year of 1989. The atmospheric ${ }^{14} \mathrm{C}$ concentration in that year was 117 pMC (Levin and Kromer 1997). The ${ }^{14} \mathrm{C}$ concentration of the seepage from whence the tritium was measured was found to be $93.1 \pm 0.3 \mathrm{pMC}$ (sample SA-4).

It took the drip water 10 years, 1989-1998, to arrive at the speleothem from the top of the cave where it fell as rain with atmospheric ${ }^{14} \mathrm{C}$ and tritium activity. The decay of ${ }^{14} \mathrm{C}$ is negligible for this period. The decrease in activity is due solely to dissolution of inorganic carbon into the water. This dissolution defines $\mathrm{A}_{0}$ for the drip water. Its magnitude is 0.8 of the atmospheric activity $(93.1 \mathrm{pMC} /$ $117.0 \mathrm{pMC}=0.796)$. This is close to the value of $80-85 \%$ that Vogel $(1967,1970)$ has used empirically for dating groundwater. Indeed this is close to the average value, of approximately $80 \mathrm{pMC}$, of several springs for which data is available in eastern Serbia (Horvatincic et al. 1989). The ages of the speleothem samples were thus recalculated using $\mathrm{A}_{0}=80 \mathrm{pMC}$. This gave a range in ${ }^{14} \mathrm{C}$ ages for the speleothem that extended 0-2300 BP (Table 1). These are the ages that are used to date the speleothem. 
The change in initial activity from 100 to $80 \mathrm{pMC}$ has a considerable affect on the reported ages. Therefore it is advisable to check if the correction of such magnitude is warranted. Uranium series ages have been often used in conjunction with ${ }^{14} \mathrm{C}$ to make correction for uncertainties in the initial ${ }^{14} \mathrm{C}$ activity. This was attempted here. However, in this case, the age of the speleothem is very young and the uranium concentration is very small. Therefore, the amount of ${ }^{230} \mathrm{Th}$ that has built up from the decay of its parent ${ }^{234} \mathrm{U}$ is very little, placing the technique at the extreme lower limits of its applicability by the analytical method. In addition, the amount of detrital thorium contamination is great. Thus, the method should be considered in this case as qualitatively indicating that the value for $\mathrm{A}_{0}$ of $80 \mathrm{pMC}$ used in the ${ }^{14} \mathrm{C}$ dating is reasonable. When a correction factor of $\mathrm{F}=1.25$ is used to correct for detrital thorium, at least for the innermost sample, a ${ }^{230} \mathrm{Th} /{ }^{234} \mathrm{U}$ age is derived that is consistent with the ${ }^{14} \mathrm{C}$ age for the same sample.

Table 5 The tritium and ${ }^{14} \mathrm{C}$ data from Zagreb, Croatia, used in calculating the initial ${ }^{14} \mathrm{C}$ values incorporated into the stalagmite from the groundwater ${ }^{\mathrm{a}}$

\begin{tabular}{ccc}
\hline Year & $\begin{array}{c}\text { Tritium in } \\
\text { the cave (TU) }\end{array}$ & $\begin{array}{c}\text { Tritium in } \\
\text { Zagreb rains (TU) }\end{array}$ \\
\hline 1990 & $21.7 \pm 0.5$ & 15.9 \\
1989 & $22.8 \pm 0.5$ & 25.0 \\
1988 & $24.1 \pm 0.5$ & 17.4 \\
1987 & $25.5 \pm 0.6$ & 22.9 \\
1986 & $27.0 \pm 0.6$ & 21.6 \\
1985 & $28.5 \pm 0.6$ & 18.6 \\
\hline
\end{tabular}

aThe tritium value in the cave seepage water was extrapolated backwards in time, correcting for the decay, to compare when there was a closest match for a comparable tritium value in regional precipitation, (Zagreb being the closest city for which data is available). The closest match would appear to be in 1989.

Table 6 The apparent thorium/uranium ages using correction factors (f), ranging from 0.7 to 1.5 , for the initial ${ }^{230} \mathrm{Th} / 232 \mathrm{Th}$ ratio

\begin{tabular}{lccccc}
\hline Sample & $\begin{array}{c}\mathrm{f}=0 \\
\text { (uncorrected) }\end{array}$ & $\mathrm{f}=0.7$ & $\mathrm{f}=1$ & $\mathrm{f}=1.25$ & $\mathrm{f}=1.5$ \\
\hline A1 & $5430 \pm 630$ & 3500 & 2650 & 1950 & 1240 \\
A6 & $6280 \pm 860$ & 3990 & 3000 & 2160 & 1310 \\
\hline
\end{tabular}

The youngest ( $80 \mathrm{pMC})$, outermost sample is "recent". As it does not contain thermonuclear-derived ${ }^{14} \mathrm{C}$ it was deposited before the bomb-derived excess ${ }^{14} \mathrm{C}$ was introduced into the atmosphere. Therefore, it should be considered to be older than 50 years.

The $\delta^{13} \mathrm{C}$ values exhibited by the stalagmite are more enriched than would be expected in a carbonate derived from the environment represented by the "average" $\mathrm{C}_{3}$-type plant $\left(\delta^{13} \mathrm{C}=-27 \%\right.$ o). At present, the rainfall is high (approximately $820 \mathrm{~mm} / \mathrm{yr}$, for the last $25 \mathrm{yr}$ ) and the $\delta^{13} \mathrm{C}$ of the infiltrating water is what would be expected from a total $\mathrm{C}_{3}$ plant coverage above the cave. The outermost section (youngest) of the stalagmite, in contrast is the most enriched, similar to that expected from a dominantly $\mathrm{C}_{4}$ environment. However, the intrusion of $\mathrm{C}_{4}$ plant communities may not be the sole explanation of the more enriched $\delta^{13} \mathrm{C}$ values. First, the average $\delta^{13} \mathrm{C}$ value $\left(-27 \%\right.$ o) of $\mathrm{C}_{3}$ plants may not be representative of the $\delta^{13} \mathrm{C}$ in the actual mixed $\mathrm{C}_{3}$ plant community of the region. There is a wide range 
in possible $\delta^{13} \mathrm{C}$ values that can be found in $\mathrm{C}_{3}$ plants that extends from $-35 \%$ o to $-20 \%$. If the more enriched isotopic values are more representative of the vegetation cover, the precipitated calcite of the stalagmite would likewise be similarly isotopically enriched.

Not enough is known concerning the proportions of $\mathrm{C}_{3}$ and $\mathrm{C}_{4}$ populations of the area at present or in the past. Direct observation would suggest that the present vegetation is overwhelmingly of $\mathrm{C}_{3}$ communities, being a thick forest. Thus, it appears that there are inorganic processes that are active in this area, most probably in a fashion similar to that encountered in England by Baker and his co-workers (1997). It is was found there that modern speleothems yield variable and isotopically enriched carbon values, in a manner that would suggest the presence of $\mathrm{C}_{4}$ plants. However, there are no $\mathrm{C}_{4}$ plants in England. Other possible soil processes, such as fermentation, could potentially also lead to enriched $\delta^{13} \mathrm{C}$ values in the residual bicarbonate, as the isotopically more depleted methane is given up to the atmosphere (Clark and Fritz 1997). The lack of botanical information concerning the present and the past regional flora would mitigate against using $\delta^{13} \mathrm{C}$ changes in the carbonate to infer changes in the plant cover. Thus, while there might have been climatically related vegetation changes, there are too many other factors that can also explain the $\delta^{13} \mathrm{C}$ values in this speleothem independent of the floral make up in the overlying soil. The drawing of climatic conclusions based solely upon the changes in $\delta^{13} \mathrm{C}$ values is not yet warranted. Thus, we merely report the $\delta^{13} \mathrm{C}$ values recorded in the speleothem, and leave the climatic interpretation based upon them open until more botanical and paleobotanical data from the region becomes available. This is not the case with $\delta^{18} \mathrm{O}$, which is independent of the type of plant cover. This isotopic method can be used for the analysis of past temperatures.

\section{CONCLUSIONS}

Regression analysis of the temperature based upon the oxygen isotopic data reveals a generalized downward trend in average temperature over the past two millennia, with superimposed warmer and cooler excursions deviating from the long-term trend. The warmer periods occurred independently of human intervention. The temperatures at these times may have risen as much as two and a half degrees above the average of the temperature trend. The unusually high temperatures of the past few years, may be evidence of either 1) a short-term climatic event or anomaly as discussed above, or 2) the evidence of anthropogenic influences that result in heating of the atmosphere, or a combination of 1) and 2) together. It is necessary to test, by further study, whether the trends witnessed here are local phenomena or are representative of regional or global climatic conditions. The general cooling trend delineated here has also been recognized in the Southern Hemisphere (Hodell et al. 2001). It may be a global feature. Perhaps, were it not for the new period of global warming, the climate of the earth would have been heading towards a period of "Neoglaciation".

\section{REFERENCES}

Baker A, Ito E, Smart PL, McEwan R. 1997. Elevated and variable values of ${ }^{13} \mathrm{C}$ in speleothems in a British cave system. Chemical Geology 136:263-70.

Clark I, Fritz P. 1997. Environmental isotopes in hydrology. New York: Lewis Publishers. 328 p.

Craig H. 1961. Standard for reporting concentrations of deuterium and oxygen-18 in natural waters. Science 133:1833-4.

Dansgaard W. 1964. Stable isotopes in precipitation. Tellus XVI:436-68.

Goudie A. 1994. Environmental change. Third Edition. Oxford: Clarendon Press. 329 p.

Hendy CH. 1971. The isotopic geochemistry of spele-
othems-I. The calculation of the effects of different models of formation on the isotopic composition of speleothems and their applicability as palaeoclimatic indicators. Geochimica et Cosmochimica Acta 35: 801-24.

Hendy CH, Wilson AT. 1968. Paleoclimatic data from speleothems. Nature 219:48-51.

Hodell D, Shemesh A, Crosta X, Kanfoush C, Guilderson T. 2001. Evidence for late Holocene Neoglaciation in the Southern Hemisphere. Quaternary Research 56: 191-8.

Horvatincic N, Srdoc D, Solar J, Tvrdikova H. 1989. Comparison of the ${ }^{14} \mathrm{C}$ activity of groundwater and re- 
cent tufa from karst areas in Yugoslavia and Czechoslovakia. Radiocarbon 31(3):884-92.

Ivanovich M, Harmon RS, editors. 1992. Uranium-series disequilibrium: applications to earth, marine, and environmental sciences. Oxford: Clarendon Press. $910 \mathrm{p}$.

Lamb HH. 1971. Volcanic activity and climate. Paleogeography, Paleoclimatology, Paleoecology 10:20330.

Lazarevic R. 1988. Ceremosnja-Pecina. Radna organizacija za ugostiteljstvo i turizam "Partizan", Kucevo. 88 p. In Serbian.

Levin I, Kromer B. 1997. Twenty years of atmospheric ${ }^{14} \mathrm{CO}_{2}$ observations at Schaunsland Station, Germany. Radiocarbon 39(2):205-18.

Libby WF. 1952. Radiocarbon dating. University of Chicago Press. $124 \mathrm{p}$.

Schwarcz HP. 1986. Geochronology and isotope geochemistry of speleothems. In: Fritz P, Fontes J-C, editors. The handbook of isotope geochemistry, the terrestrial environment. B, Volume 2. Amsterdam: Elsevier. p 271-304.

Vogel JC. 1967. Investigation of groundwater flow with radiocarbon. Isotopes in Hydrology. Vienna: IAEA. p 355-68.

Vogel JC. 1970. Carbon-14 dating of groundwater. Radioisotopes in Hydrology. Vienna: IAEA. p 225-39.

Wang Y, et al. 1998. Carbon cycling in terrestrial environments. In: Kendall C, McDonnell JJ, editors. Isotope tracers in catchment hydrology. Elsevier Science. 578 p.

Wigley TML, Plummer LN, Pearson FJ. 1978. Mass transfer and carbon isotope evolution in natural water systems. Geochimica et Cosmochimica Acta 42:111740.

Yonge CJ, Ford DC, Gray J, Schwarcz HP. 1985. Chem. Geol. (Isot. Geosci. Sect.) 58:97-105. 